\title{
Physical disturbances in an Australian kelp community. I. Temporal effects
}

\author{
Steven J. Kennelly* \\ Institute of Marine Ecology, Zoology AO8, University of Sydney, N.S.W. 2006, Australia
}

\begin{abstract}
Physical disturbances leading to clearances of kelp canopies were investigated for their effects on understorey species. First, frequencies and types of natural disturbances in a kelp forest were quantified from data on storm activity and underwater surveys. Storms removed parts of kelp plants, whole plants and groups of plants. The latter led to clearings and increased the quantity of light reaching the substratum. Second, manipulative experiments throughout 1 yr determined temporal variation in the effects of canopy removal on the understorey assemblage. Replicate areas in the kelp forest were cleared and others left as controls. The microscopic assemblage of species was sampled as well as macroscopic plants and animals. On substrata cleared in spring, summer and autumn, turf dominated after initial increases in the covers of microalgae and microinvertebrates. This turf inhibited kelp recruitment during dense recruitment in winter and persisted for up to $2 \mathrm{yr}$, until kelps encroached into clearings from the edges. In areas cleared during dense kelp recruitment (in winter), kelp colonized the substratum together with filamentous and turf algae. The kelp quickly developed a canopy, leading to the decline of turf species. These results demonstrate inhibitory successions: kelp canopies and areas of turf both occupied the substratum and inhibited the establishment of the other. The type of vegetation found in any place at any time depended on the timing of, and time since, the last removal of kelp.
\end{abstract}

\section{INTRODUCTION}

Physical disturbances affect the distributions and abundances of species living in many ecosystems (Pickett \& White 1985). The timing, frequency and severity of physical disturbances may determine which species are removed and therefore the extent to which successional mechanisms can proceed (Levin \& Paine 1974, Sousa 1984, Connell \& Keough 1985). In particular, physical disturbances influence marine communities by renewing the limiting resource of space for the colonization of intertidal (e.g. Dayton 1971) and subtidal species (e.g. Connell \& Keough 1985).

In sublittoral kelp forests the main physical disturbances are due to storms and associated water turbulence. These dislodge kelps and have many subsequent effects on species assemblages in understorey communities (Rosenthal et al. 1974, Dayton \& Tegner 1984, Dayton et al. 1984, Santelices \& Ojeda 1984, Ebling et al. 1985). Other disturbances that occur in

\footnotetext{
- Present address: Fisheries Research Institute, N.S.W Department of Agriculture, PO Box 21, Cronulla, N.S.W 2230, Australia
}

kelp forests are due to humans and especially involve harvesting kelp plants or parts of kelp canopies for foods and alginates (Kimura \& Foster 1984, Smith 1985). Natural and man-induced disturbances lead to the denudation of kelp and have been the foci of recent ecological work in kelp communities (for reviews see Dayton 1985, Foster \& Schiel 1985).

Despite the number of studies of the effects of canopy removal on kelp communities, few have considered temporal variation in effects of physical disturbances on species (but see Ojeda \& Santelices 1984, Reed \& Foster 1984). This is important because the species composition of propagules at times of disturbance may vary with the season in which different species reproduce (Sutherland \& Karlson 1977, Ambrose \& Nelson 1982, Kennelly \& Larkum 1984). Effects caused by canopy removals in one season may differ for clearances occurring at other times.

In this article I quantified the timing, frequency and severity of natural physical disturbances which led to the removal of canopies in a particular kelp forest. Manipulative experiments determined the consequences on the structure of the benthic community due to removing whole kelp canopies at different times of the year. 


\section{MATERIALS AND METHODS}

Study site. The study was conducted $4 \mathrm{~m}$ below lowtide level in a kelp forest in Fairlight Bay, Port Jackson,

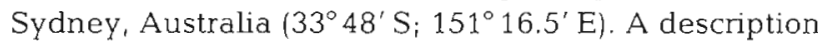
may be found in Kennelly (1983). The kelp at Fairlight is Ecklonia radiata (C. Agardh J. Agardh), a stipitate species (about $0.9 \mathrm{~m}$ tall) that forms dense beds along the coast of New South Wales (plant density approximately $30 \mathrm{~m}^{-2}$ ).

The assemblage of species under the kelp canopy at Fairlight contains several types of encrusting algae, sponges, bryozoans, ascidians, and brown, red and green algae. There are also gaps in the canopy formed by storms that dislodge kelps. The detached plants entangle with other kelps and assist in dislodging them (Kennelly pers. obs.; see also Rosenthal et al. 1974, Dayton et al. 1984). In the clearings thus formed, the substratum is dominated by a short turf comprised of a uniform cover of low-lying, dictyotalean algae. When observed with an underwater microscope (Kennelly \& Underwood 1984) the benthic assemblage of species includes diatoms, blue-green and filamentous algae, juveniles of larger plants (including kelp) and microscopic animals lostracods, amphipods and minute gastropods). Fine detritus settles from the water column and is found amongst these organisms.

The kelp bed faces the open sea to the south-east. Thus, when strong south to south-east swells occur off the New South Wales coast, the forest at Fairlight is subject to great water turbulence and kelp plants become detached. To determine the timing of these periods of intense wave action, I obtained records of the height of south to south-east swells occurring off the central New South Wales coast from August 1983 to August 1984. These data were compared with data on the frequency of removals of canopies by storms obtained during the same period below.

Survey of kelp populations and natural clearances. Surveys were made every 2 mo from August 1983 to August 1984, to determine the frequency of physical disturbances to kelp plants at Fairlight. During each sample period, three $20 \mathrm{~m}$ transects were placed randomly in the kelp forest using a tape. At each metre along the tape, metre rules were placed perpendicular to the tape to provide a $1 \times 1 \mathrm{~m}$ quadrat. In each square, the number of adult kelps ( $>150 \mathrm{~mm}$ total length), and the number of juvenile kelps $(<150 \mathrm{~mm}$ : younger than $2 \mathrm{mo}$ ) were recorded. Also recorded were the numbers of kelp plants lacking laminae, and those lacking both laminae and stipes.

The frequency of gaps appearing in the kelp canopy was determined by recording the sizes of openings in the canopy $\left(>0.5 \mathrm{~m}^{2}\right)$ that occurred along each random $20 \mathrm{~m}$ transect during each sample period.
The amount of light reaching the understorey community (measured in $\mu \mathrm{E} \mathrm{m}^{-2} \mathrm{~s}^{-1}$ ) was estimated using a Licor (LI-188) quantum photometer under the kelp canopy and in clearings, on replicate overcast and sunny days.

Effects on benthic community of kelp clearances in different seasons. Four sites $(2 \mathrm{~m} \times 2 \mathrm{~m})$ were cleared of all kelp and 4 were left uncleared in December 1982 (summer), March 1983 (autumn), June 1983 (winter) and September 1983 (spring). Only stipes and fronds were removed (leaving holdfasts) as the removal of holdfasts affects the identity of colonizing species by providing clean primary substratum (Kennelly 1987). The presence of holdfasts is also known to have no influence on the subsequent establishment of later colonists in clearings (Kennelly 1987).

Sampling involved 2 techniques to include as many understorey organisms as possible. All field data were recorded on a tape recorder adapted for use underwater (Kennelly \& Underwood 1984). Macroscopic benthic organisms were sampled in all experiments using 3 randomly placed, $30 \times 30 \mathrm{~cm}, 100$-point quadrats to record percentage covers (using the point-intersect method) in the centre of each cleared area and control. Numbers of individual kelp plants and benthic animals within each quadrat were also recorded. This quadrat size was chosen to allow easy maneuvring between kelp stipes. The accuracy and repeatability of data gathered using this quadrat were checked in a series of comparisons of quadrats of different sizes and repeated sampling at the same locations (Kennelly 1986). These tests revealed no significant inaccuracies (analyses of variance, $p>0.05$ ).

The abundances of microscopic organisms were determined using an underwater microscope (Kennelly \& Underwood 1984) at a magnification of $53 \times$ (each field of view covered $5 \times 5 \mathrm{~mm}$ of substratum). A 9point graticule in the eyepiece was used to estimate the relative covers of species. The numbers of mobile microscopic animals within each field of view were also recorded. Eight randomly selected, replicate fields of view were sampled in each area.

Sampling was repeated after 2,4 and 8 wk intervals. It was found in other studies (Kennelly 1983, Kennelly 1986) that this was sufficient to detect changes in the structure of both the macroscopic and microscopic assemblages of species.

The data from this experiment consisted of: (1) macroscopic percent covers of 39 species of macroscopic algae, sponges, ascidians and bryozoans; (2) macroscopic percent covers of a layer of fine sediment containing microscopic algae, animals and silt; (3) macroscopic percent cover of bare rock: (4) abundances of 7 species of large mobile animals; (5) microscopic relative covers of 19 species of microscopic, sessile organ- 
isms; and (6) abundances of 9 microscopic invertebrate taxa. Organisms were identified in the field to species in most cases. Some organisms, however, could only be identified to genus, and for other genera (e.g. Peyssonnelia/Hildenbrandia complex) data had to be combined as sectioning was required to differentiate genera

The data for each taxonomic group were considered for effects of experimental treatments. Further, the numbers of species within each quadrat were used to estimate the species richness in each replicate for both sampling procedures. Data were analysed by tests of homogeneity of variances, the relevant 3-factor analysis of variance, and Student-Newman-Keuls multiple comparisons (significance level $p=0.05$ ). Those sets of data that showed significant variation among experimental treatments are discussed below.

\section{RESULTS}

\section{Physical disturbances and abundance of kelp}

Data on the frequency and intensity of south and south-east swells (Fig. 1) showed that only 3 episodes of very rough seas occurred throughout the 13 mo period August 1983 to August 1984: in October 1983, May 1984 and June/July 1984. Only during these periods of very rough weather could kelp plants be detached in any significant number (pers. obs. in such conditions).

Juvenile kelp plants were common at the study site in August 1983 (Fig. 2A). Such recruitment of Ecklonia radiata usually occurs around July and August every year along the New South Wales coast (Kennelly unpubl. data). The numbers of these juveniles then decreased throughout the year as they grew into the classification of adult kelps in early 1984. New recruits appeared in August 1984 after another recruitment episode in July/August 1984. The numbers of adult kelp plants at the study site were lowest in late 1983 (following the early October storm; Fig. 2B). Adult plants increased in abundance from January 1984 onwards as the juveniles from the July 1983 recruitment grew. The numbers of adults then decreased after the June/July 1984 storm.

The numbers of plants with both stipe and lamina removed (i.e. just the holdfast remaining) increased in late 1983 (after the October storm), then declined in early 1984 before increasing again in the August 1984 sample (after the July 1984 storm; Fig. 2C). The numbers of plants with laminae only completely detached decreased initially during the survey, but then increased from March 1984 until August 1984 (Fig. 2D). This illustrates no consistent correlation with effects of storms.

The percent of each sampled area without kelp canopy (i.e. a clearing; Fig. 3A) showed an increase in late 1983 after the October storm. As the canopy grew after this storm (from December to April 1984), the clearings became smaller. After the May and July storms of 1984, the cleared area in the forest was greater. The sizes of these clearings varied from $0.5 \mathrm{~m}^{2}$ to $60 \mathrm{~m}^{2}$ throughout the survey (Fig. 3B). Most clearings were less than $10 \mathrm{~m}^{2}$.

Light measurements showed that the presence of a kelp canopy reduced the amount of light reaching the substratum by about $95 \%$, on both sunny and cloudy days, as compared to clearings (Table 1).

\section{Effects of canopy removals in different seasons}

In all clearances made in different seasons, there was a tendency for the encrusting algae Peyssonnelia

\section{CONDITION OF SEA}

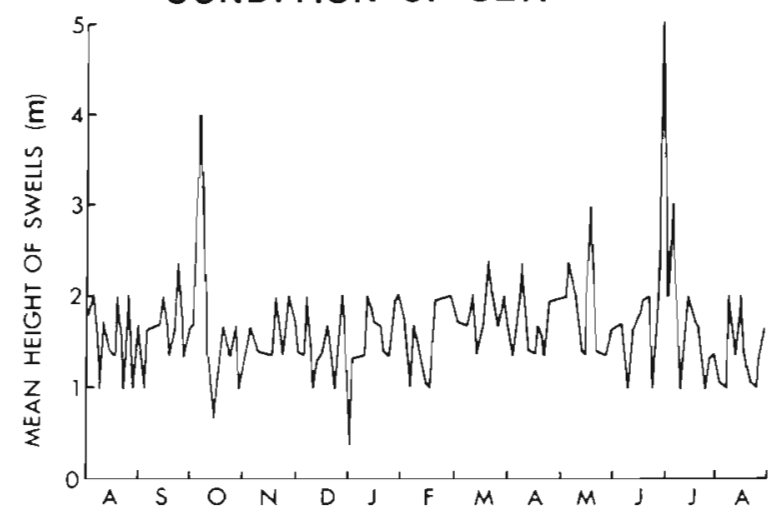

Fig. 1. Mean height of south to south-east swells in the Sydney region during a 13 mo period $(n=3$ d)

\section{A JUVENILE KELPS}

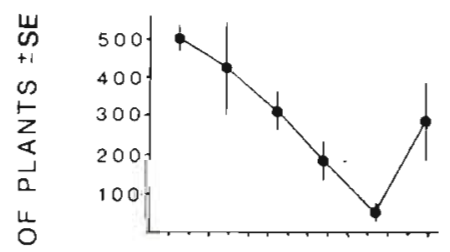

B ADULT KELPS
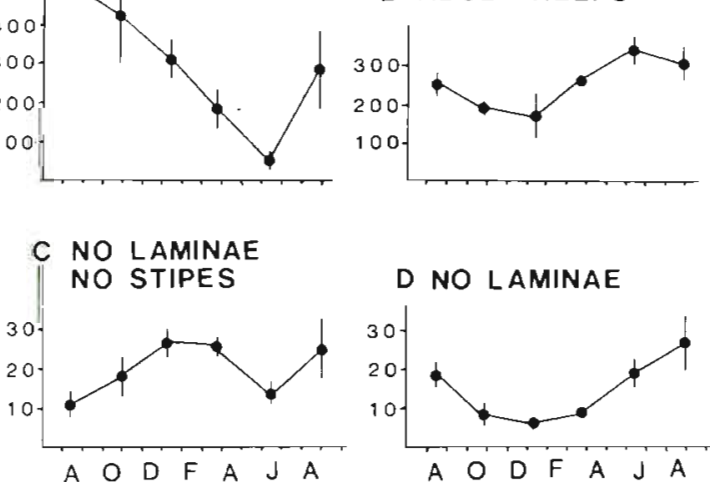

Fig. 2. Mean numbers (per $\mathrm{m}^{2}$ ) over the 13 mo period of (A) juvenile and (B) adult kelp plants; (C) kelp plants with laminae and stipes missing; (D) kelp plants with laminae missing $(\mathrm{n}=60)$ 


\section{A CLEARINGS}
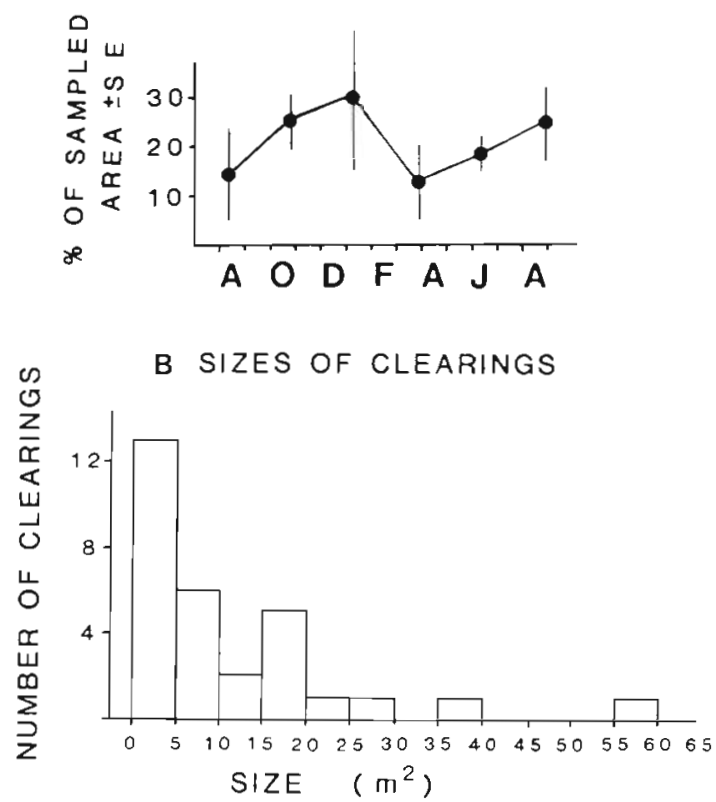

Fig. 3. (A) Mean percentage area of clearings found in the total sampled area during survey $(n=3)$; $(B)$ size frequency histogram for these clearings $(n=30)$

Table 1. Light intensity under the kelp canopy and in clearings $\left(>1 \mathrm{~m}^{2}\right)$ on sunny and cloudy days. Values in $\mu \mathrm{Em}^{-2} \mathrm{~s}^{-1}$ $\pm 1 \mathrm{SE}, \mathrm{n}=18$

\begin{tabular}{|lcc|}
\hline & Under canopy & In clearings \\
\hline Sunny days & $8.9(1.7)$ & $178.9(3.5)$ \\
Cloudy days & $7.3(1.9)$ & $140.2(1.7)$ \\
\hline
\end{tabular}

gunniana J. Agardh/Hildenbrandia prototypus Nardo to decrease in cover (Fig. 4A). In clearances initiated in winter, cover then increased after $12 \mathrm{wk}$. For clearings made in autumn this increase occurred after $32 \mathrm{wk}$. For other seasonal clearances this increase began to occur after $48 \mathrm{wk}$. The filamentous alga Giffordia mitchelliae (Harvey) increased following summer and spring clearances (Fig. 4B) and decreased again within $12 \mathrm{wk}$. No such increase occurred after winter or autumn clearances. Cover of the dictyotalean algae Zonaria spp./Lobophora variegata (Lamoroux) Womersley increased in clearings made in all seasons (Fig. 4C). Winter clearings had a smaller cover than clearings in other seasons.

The cover of Ecklonia radiata holdfasts remained small in clearings made in all seasons except winter (Fig. 5A.). In winter clearings, the cover of these holdfasts increased dramatically at $16 \mathrm{wk}$. In the other seasonal clearances, the cover of E. radiata holdfasts began to increase after $40 \mathrm{wk}$.
The cover of the sediment layer (a mixture of fine silt, unicellular and filamentous algae and micro-invertebrates) increased up to $8 \mathrm{wk}$ in summer clearances and then decreased again (Fig. 5B). In winter clearances. sediment cover decreased, reaching a very low value after $24 \mathrm{wk}$. In natural, uncleared treatments sampled initially in summer, there was an increase in the cover of the sediment layer up until $24 \mathrm{wk}$ when it decreased again

Table 2 summarizes cover fluctuations for the above species and all remaining species, following clearance of kelp in different seasons. The covers of encrusting algae Didemnum sp. and Myxilla sp. decreased in all seasonal clearances. Zonaria spp., Lobophora variegata and Sargassum spp. increased in all seasonal clearings. Other species, (Padina fraseri [Greville], Dictyota spp., Colpomenia sinuosa [Roth] Derbes \& Solier, Haliptilon officinalis Lamouroux, Amphiroa sp. and the microscopic algae Enteromorpha spp. and Giffordia mitchelliae) showed increases only in clearings made at certain times, indicating that these species occur in clearings only if such physical disturbances coincide with their times of settlement. Juvenile Ecklonia radiata only occurred in clearings initiated in winter. The green alga Ulva lactuca (Linnaeus), the sediment layer, and microscopic silt fluctuated in abundances in no clear pattern and independent of clearing. The species richness of the macroscopic assemblage was found to be less in cleared areas than in uncleared controls.

\section{DISCUSSION}

The survey data (Fig. 1, 2 \& 3) showed that physical disturbances affected the abundances and condition of kelp plants and the sizes and numbers of clearings that occurred in the kelp forest. Clearances in the canopy greater than about $1 \mathrm{~m}^{2}$ caused increases in the level of light reaching the substratum (Table 1). The results from experimental clearances showed that after clearing (and subsequent increases in light levels) there was an initial cover on the substratum of the microscopic filamentous algae Enteromorpha spp. and Giffordia mitchelliae (Table 2). There was also seen to be an increase in numbers of micro-invertebrates, using the underwater microscope (Kennelly, pers. obs.). The presence of these microscopic organisms in the pattern of colonization of natural substrata in clearings in kelp forests has not been previously demonstrated. This phase was quite quickly followed by the substratum being covered by turf algae

If these gaps in the canopy occurred in summer, autumn or spring, Zonaria spp., Lobophora variegata and other turf species grew enough to completely 
A Peyssonelia/Hildenbrandia COMPLEX

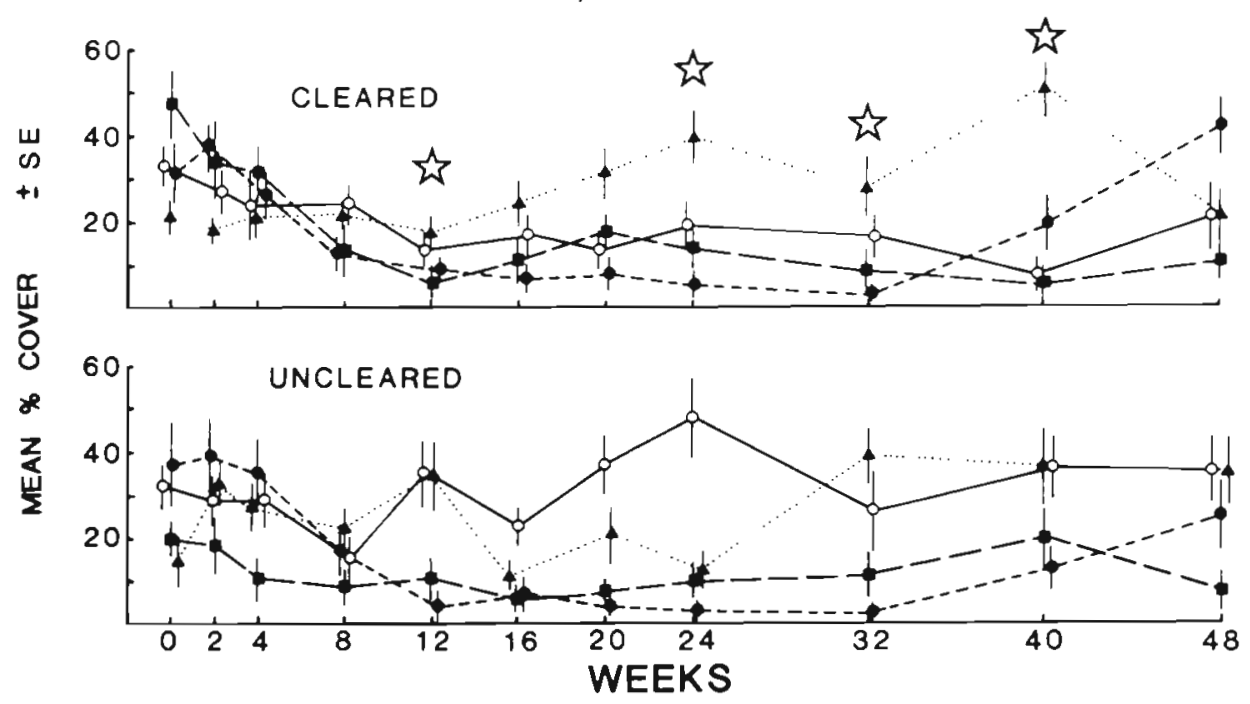

B Giffordia mitchelliae

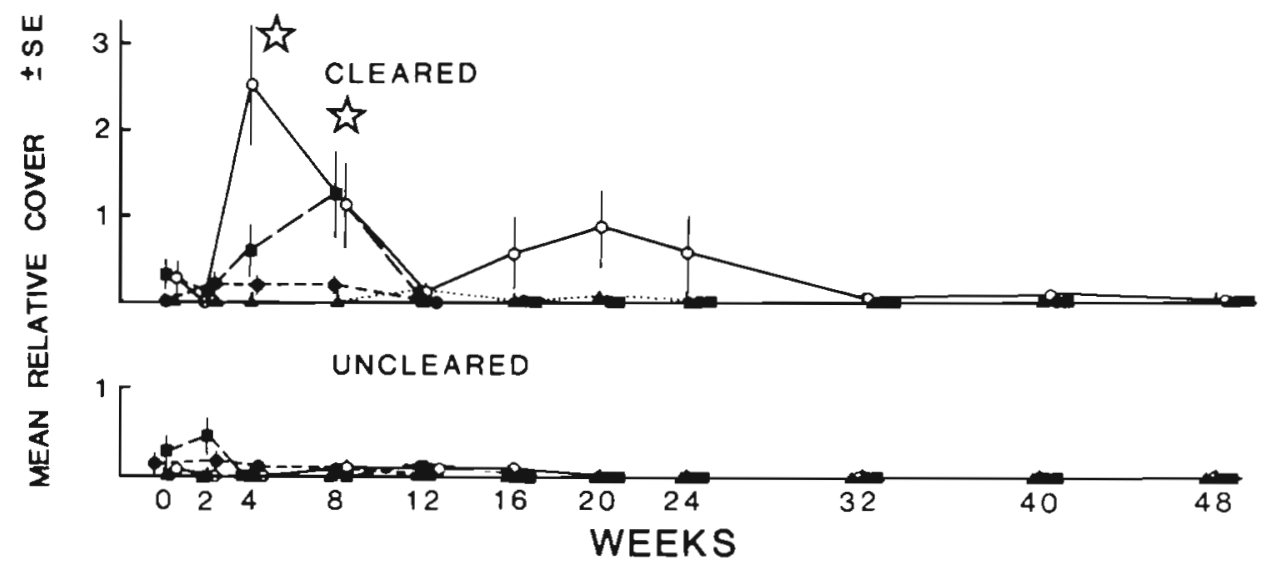

C Zonaria Lobophora COMPLEX

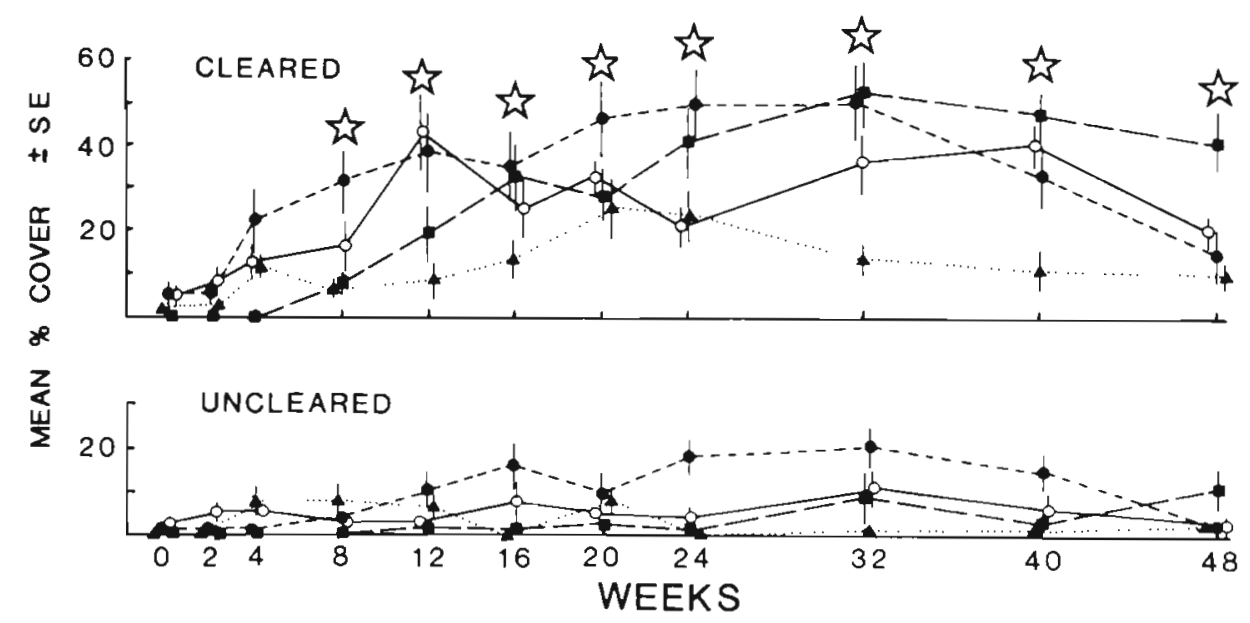

Fig. 4. Effects on the cover of (A) Peyssonelia/Hildenbrandia complex, (B) Giffordia mitchelliae, and (C) Zonaria/Lobophora complex due to clearing kelp from areas in different seasons of the year. Treatments are cleared and uncleared areas initiated in winter (4), summer ( $(\bullet)$ autumn ( $\bullet$ ) and spring (o). $(n=12)$. is denotes a significant difference among the plotted means determined in the analysis of variance of the data and SNK comparisons at that time of sampling. $\mathrm{X}$-axis is the time after clearing 

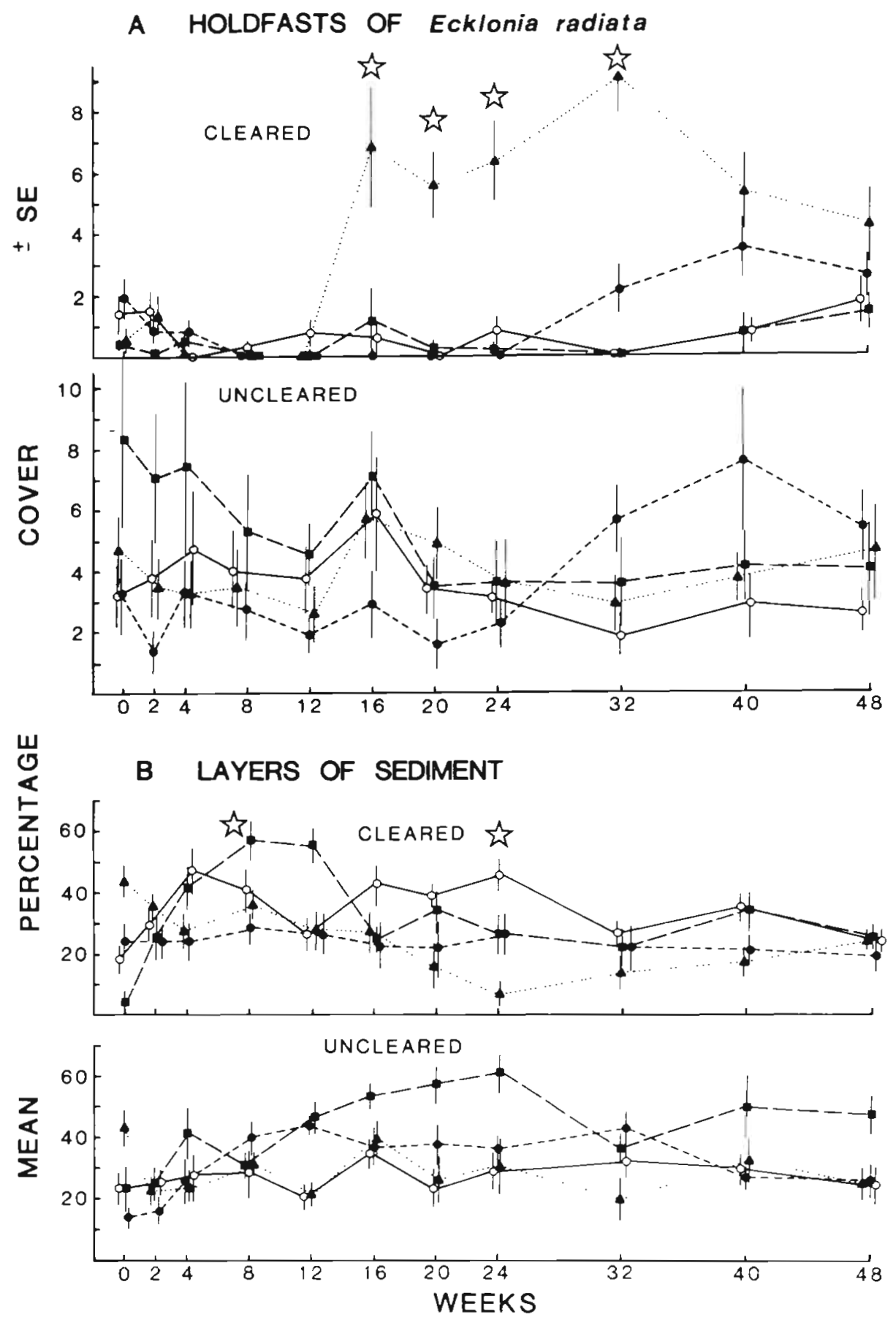

Fig. 5. Effects on cover of (A) holdfasts of Ecklonia radiata and (B) sediment layer due to clearing kelp from areas in different seasons of the year. For explanation of symbols, see legend to Fig. 4

occupy the substratum (see also Chapman 1984, Dayton et al. 1984). These areas remained covered by turf for at least 12 mo. Over this period, kelp plants settled on the edges of these clearings, grew, and reduced the size of the gap in the canopy. After another $12 \mathrm{mo}$, these kelps became abundant and large enough to produce a canopy over the clearings and the turf began to die out (pers. obs.) (see discussion by Connell \& Keough 1985 of this form of patch invasion).

If, however, gaps in the canopy occurred at a time of kelp recruitment (in winter), the abundances of many species are different (Table 2). In these plots, Ecklonia radiata recruited soon after clearing. As these recruits developed into a canopy, the structure of the under- 
Table 2. Summary of results from experiment examining the effects of removing kelp canopies in different seasons. Time after manipulation at which an increase $(+)$ or decrease $(-)$ occurred is given in weeks. Maximum and minimum means for each species are given; all data are from macroscopic sampling (quadrat size: $900 \mathrm{~cm}^{2}$ ) except those marked 'micro' (quadrat size: $25 \mathrm{~mm}^{2}$ )

\begin{tabular}{|c|c|c|c|c|c|}
\hline Taxon & Range of means & Summer & Autumn & Winter & Spring \\
\hline \multicolumn{6}{|c|}{ Species that decrease after clearing } \\
\hline -Peyssonelia/Hildenbrandia & $(3-50 \%)$ & $-8+48$ & $-8+48$ & $-8+24$ & $-8+48$ \\
\hline Didemnum sp. & $(0-22 \%)$ & -8 & -8 & $-8+32$ & -8 \\
\hline Myxilla sp. & $(0-16 \%)$ & -8 & -8 & -8 & -8 \\
\hline \multicolumn{6}{|c|}{ Microscopic algae - initial occupiers of clearings } \\
\hline Enteromorpha spp. (micro) & $(0-44 \%)$ & $+4-12$ & ns & ns & $+4-12$ \\
\hline - Giffordia mitchelliae (micro) & $(0-28 \%)$ & $+8-12$ & ns & ns & $+4-12$ \\
\hline Unicellular algae (micro) & $(0-22 \%)$ & ns & ns & ns & ns \\
\hline \multicolumn{6}{|c|}{ Turf algae - occupied the substratum after filamentous algae } \\
\hline - Zonaria/Lobophora & $(0-55 \%)$ & $+12-40$ & $+12-40$ & $+20-32$ & $+12-40$ \\
\hline Colpomenia sinuosa & $(0-16 \%)$ & $+6-8$ & ns & ns & ns \\
\hline Padina fraseri & $(0-5 \%)$ & $+12-16$ & $+4-8$ & ns & ns \\
\hline Sargassum spp. & $(0-5 \%)$ & +32 & +12 & $+20-48$ & $+12-48$ \\
\hline Haliptilon/Amphiroa & $(0-2 \%)$ & ns & ns & +32 & ns \\
\hline Dictyota spp. & $(0-2 \%)$ & ns & $+8-16$ & $+8-48$ & $+8-48$ \\
\hline \multicolumn{6}{|l|}{ Recovery by kelp } \\
\hline Juvenile Ecklonia radiata & $(0-19$ plants $)$ & ns & ns & $+8-24$ & ns \\
\hline - Ecklonia radiata holdfasts & $(0-10 \%)$ & +40 & +40 & +16 & +40 \\
\hline \multicolumn{6}{|c|}{ Abundances fluctuated - independent of clearing } \\
\hline - Sediment layer & $(4-60 \%)$ & $+8-16$ & ns & -24 & ns \\
\hline Fine silt (micro) & $(1-83 \%)$ & +4 & ns & ns & ns \\
\hline Ulva lactuca & $(0-4 \%)$ & ns & $+8-20$ & $+8-12$ & $+16-32$ \\
\hline \multicolumn{6}{|l|}{ Species richness } \\
\hline & (6-9 species) & -8 & -8 & -8 & -8 \\
\hline
\end{tabular}

storey community changed to be similar to uncleared control areas, with low covers of turf and high covers of encrusting algae Didemnum sp. and holdfasts of $E$. radiata. In this case, the turfing algae did not follow filamentous algae in the succession as the community returned to its state of encrusting algae, sponges and ascidians under a kelp canopy.

When Ecklonia radiata recruited to winter clearings, they did not at the same time recruit to clearings made at other times of the year. This indicates that the turf that had become established in these clearings inhibited the dense recruitment of kelp that occurs around July/August each year. To fully determine seasonal influences (as against merely temporal variations), the experiments described in this paper would need to be repeated in different years, but this was beyond the logistic scope of the project.

In terms of succession theory, the replacement of microscopic filamentous algae by turf after 6 to $8 \mathrm{wk}$ may be a facilitative event (sensu Connell \& Slatyer 1977 ) if filamentous algae changed the conditions of the substratum to enhance the establishment of turf. More likely, however, this is evidence for tolerance, where all species arrived soon after the disturbance and the slower growing turf took more time to grow up and over the faster growing filamentous and unicellular algae. Small numbers of microscopic sporelings of dictyotalean algae were present soon after disturbance, as seen in the underwater microscope samples. These data were not presented above as abundances were small and there were no significant differences among treatments in analyses. The turf appear to eventually outcompete the filamentous species for a shared resource (probably light) made available by the removal of the kelp plants. This pattern is similar to that found by Foster (1975) in one of the first studies of algal successions in kelp forests.

In many other studies of kelp clearances, canopy removal usually led to quite significant changes in the structure of the understorey community (Pearse \& Hines 1979, Dayton et al. 1984, Reed \& Foster 1984, Santelices \& Ojeda 1984, but see Chapman 1984). It has also been shown that turf species in kelp communities may inhibit recruitment of kelps (Ambrose \& Nelson 1982, Dayton et al. 1984). Such a situation occurs in the kelp forest at Fairlight. Removal of kelps led to the 
growth of a turf which inhibited further kelp recruitment. If, however, removal of kelp occurred at a time of kelp settlement, turf algae did not get established and the recruiting kelp developed a canopy that ultimately reduced the cover of turf.

These interactions could be viewed as inhibitory successional events with the dominating plants being either turf or canopy species. Which species dominates at any time depends upon the recent history of that place with respect to physical disturbance and the synchrony of those disturbances with recruitment by the kelp. The timing of recruitment of turf is less important in these interactions because it is more or less perennial.

The alternation between 2 separate assemblages of species (turf versus areas of kelp) suggests a nonequilibrial organization of this kelp community (see also Sutherland 1974). The substratum in turf areas, however, ultimately becomes dominated by encrusting species after encroachment by kelps from the edges of clearings (see also Connell \& Keough 1985). This suggests a tendency for the community to head towards a 'climax' assemblage (Connell \& Slatyer 1977), dominated by a thick kelp canopy overlying encrusting species. Whilst such a climax community is usually found in the kelp forest, regular physical disturbance means that this climax assemblage is often replaced by filamentous or turfing species. Such physical disturbance thus produces a mosaic of vegetation types within the community, the structure of which is dependent on both the timing of, and time since, the last physical disturbance (see also Sousa 1984). Other factors also act with physical disturbances to bring about more complicated mosaics within this community. Effects of macro- and micro-grazers (Kennelly 1986), and the demography of individual species will also influence the structure of the benthic community.

It is interesting to note that the species richness of these different assemblages was found to be smallest in the non-equilibrium case (areas of turf) and greatest in the 'climax' community (kelp-dominated areas) (Table 2). This is in contrast to other studies of climax communities in marine systems, where climax assemblages have been characterized by low diversity attributed to the presence of a competitively dominant species (Paine 1974; see discussion by Sousa 1985). Despite the presence of a competitive dominant here (kelp plants), diversity is greatest in this equilibrial state. This anomaly between past studies and the present study may be a result of the extent to which the assemblages were exhaustively sampled.

Acknowledgements. This study was part of a $\mathrm{Ph}$. D. project supported by a University of Sydney Post-graduate Research Award and funds from the University of Sydney Research
Grant. I sincerely thank Dr A. J. Underwood for his help and guidance at most stages of this research. I especially thank Dr K. McGuinness and anonymous referees for critically reading the manuscript and Drs J. H. Choat, M. S. Foster and P. K. Dayton for helpful discussions. The Federal Bureau of Meterology provided data concerning swell conditions. I am grateful to L. Bragg and M. Ricketts for assistance with the figures and B. Mapstone, G. Graf, P. Scanes and P. Kennelly for assistance with field work.

\section{LITERATURE CITED}

Ambrose, R. F., Nelson, B. V. (1982). Inhibition of giant kelp recruitment by an introduced brown alga. Botanica mar. 25: $265-267$

Chapman, A. R. O. (1984). Reproduction, recruitment and mortality in two species of Laminaria in south-west Nova Scotia. J. exp. mar. Biol. Ecol. 78: 99-109

Connell, J. H., Keough, M. J. (1985). Disturbance and patch dynamics of subtidal marine animals on hard substrata. In: Pickett, S. I A., White, P. S. (ed.) The ecology of natural disturbance and patch dynamics. Academic Press, London, p. $125-152$

Connell, J. H., Slatyer, P. O. (1977). Mechanisms of succession in natural communities and their role in community stability and organization. Am Nat. 111. 1119-1144

Dayton, P. K. (1971). Competition, disturbance and community organisation: the provision and subsequent utilization of space in a rocky intertidal community. Ecol. Monogr. 41: 351-389

Dayton, P. K. (1985). Ecology of kelp communities. Ann. Rev. Ecol. Syst. 16: 215-245

Dayton, P. K., Tegner, M. (1984). Catastrophic storms, El Niño, and patch stability in a Southern California kelp community. Science 224: 283-285

Dayton, P. K., Currie, V., Gerrodette, T., Keller, B. D., Rosenthal, R., Ven Tresca, D. (1984). Patch dynamics and stability of some California kelp communities. Ecol. Monogr. 54: 253-289

Ebling, A. W., Laur, D. R., Rowley, R. J. (1985). Severe storm disturbances and reversal of community structure in a southern California kelp forest. Mar. Biol. 84: 287-294

Foster, M. S. (1975). Algal succession in a Macrocystis pyrifera forest. Mar. Biol. 32: 313-329

Foster, M. S., Schiel, D. R. (1985). The ecology of giant kelp forests in California: a community profile. U.S. Fish and Wildl. Serv., Biol. Rep. 85

Kennelly, S. J. (1983). An experimental approach to the study of factors affecting algal colonization in a sublittoral kelp forest. J. exp. mar. Biol. Ecol. 68: 257-276

Kennelly, S. J. (1986). The structure of a sublittoral kelp community. Ph. D. thesis, Univ, of Sydney

Kennelly, S. J. (1987). Physical disturbances in an Australian kelp community. II. Effects on understorey species due to differences in kelp cover. Mar. Ecol. Prog. Ser. 40: 155-165

Kennelly, S. J., Larkum, A. W. D. (1984). A preliminary study of temporal variation in the colonization of subtidal algae in an Ecklonia radiata community. Aquat. Bot. 17: 275-282

Kennelly, S. J., Underwood, A. J. (1984). Underwater microscopic sampling of a sublittoral kelp community. J. exp mar. Biol. Ecol. 76: 67-78

Kimura, R. S., Foster, M. S. (1984). The effects of harvesting Macrocystis pyrifera on the algal assemblage in a giant kelp forest. Hydrobıologia 116: 425-428 
Levin, S. A., Paine, R. T. (1974). Disturbance, patch formation and community structure. Proc. natn. Acad. Sci. U.S.A. 71. $2744-2747$

Ojeda, F. P., Santelices, B. (1984). Ecological dominance of Lessonia nigrescens (Phaeophyta) in central Chile. Mar Ecol. Prog. Ser. 19: 83-91

Paine, R. T (1974). Intertidal community structure: experimental studies on the relationship between a dominant competitor and its principal predator. Oecologia (Berl.) 15: 93-120

Pearse, J. S., Hines, A. H. (1979). Expansion of a central California kelp forest following the mass mortality of sea urchins. Mar. Biol. 51: 83-91

Pickett, S. T. A., White, P. S. (1985). The ecology of natural disturbance and patch dynamics. Academic Press, London

Reed, D. C., Foster, M. S. (1984). The effects of canopy shading on algal recruitment and growth in a giant kelp forest. Ecology 65: 937-948

Rosenthal, R. J., Clarke, W. D., Dayton, P. K. (1974). Ecology and natural history of a stand of giant kelp, Macrocystis pyrifera off Del Mar, California. Fish. Bull. U.S. 72 670-684

Santelices, B., Ojeda, F. P. (1984). Effects of canopy removal on the understorey algal community structure of coastal forests of Macrocystis pyrifera from southern South America. Mar Ecol. Prog. Ser. 14: 165-173

Smith, B. D. (1985). Recovery following experimental harvesting of Laminaria longicruris and $L$. digitata in southwestern Nova Scotia. Helgoländer Meeresunters. 39: 83-101

Sousa, W P. (1984). Intertidal mosaics: patch size, propagule availability and spatially variable patterns of succession. Ecology 65: 1918-1935

Sousa, W. P. (1985). Disturbance and patch dynamics on rocky intertidal shores. In: Pickett, S. T. A., White, P. S. (ed.). The ecology of natural disturbance and patch dynamics. Academic Press, London, p. 101-124

Sutherland. J. P. (1974). Multiple stable points in natural communities. Am. Nat. 108: 859-873

Sutherland, J. P., Karlson, R. H. (1977). Development and stability of the fouling community at Beaufort, North Carolina. Ecol. Monogr 47: 425-446

This article was presented by Professor J. S. Pearse; it was accepted for printing on July 17, 1987 